essentially as described for modification of Rho with dermonecrotic toxin $(\mathrm{DNT})^{21}$. In general, recombinant proteins were incubated with GST-CNF1 in a molar ratio of $10: 1$ or 16:1 (GTPase:GST-CNF1) (or as indicated) in a reaction buffer containing $20 \mathrm{mM}$ Tris- $\mathrm{HCl}$, $\mathrm{pH} 7.5,10 \mathrm{mM} \mathrm{MgCl}_{2}, 1 \mathrm{mM}$ DTT, $1 \mathrm{mM}$ EDTA for $3 \mathrm{~h}$ at $37^{\circ} \mathrm{C}$.

Nucleotide-binding assay. RhoA was modified as described above but with GST-CNF1 immobilized to glutathione-Sepharose beads to remove the toxin after the reaction. $0.5 \mu \mathrm{M}$ RhoA, CNF1-modified RhoA or Gln63Glu-RhoA were incubated in buffer $\mathrm{C}(150 \mathrm{mM} \mathrm{NaCl}, 2.5 \mathrm{mM} \mathrm{MgCl}, 10 \mathrm{mM}$ triethanolamine- $\mathrm{HCl}, \mathrm{pH} 7.5)$ at $37^{\circ} \mathrm{C}$. After addition of $2 \mu \mathrm{M}$ mantGDP, the increase in mant-fluorescence upon binding to RhoA was monitored in a Perkin Elmer LS50B luminescence spectrometer. The emission was measured at $444 \mathrm{~nm}$ with excitation at $357 \mathrm{~nm}$.

GTPase assay. Recombinant Rho proteins modified by CNF1 were loaded with $\left[\gamma^{-32} \mathrm{P}\right]$ GTP for $5 \mathrm{~min}$ at $37^{\circ} \mathrm{C}$ in loading buffer $(10 \mathrm{mM}$ EDTA, $2 \mathrm{mM}$ DTT, $50 \mathrm{mM}$ Tris- $\mathrm{HCl}$, pH 7.5). $\mathrm{MgCl}_{2}$ was then added to $12 \mathrm{mM}$. Unbound nucleotide was removed by gel filtration or unlabelled GTP $(5 \mathrm{mM})$ was added. For GAP stimulation, $40 \mathrm{nM}$ of p50 rhoGAP was added (Rho at $0.8 \mu \mathrm{M}$ ). GTPase activities were determined by measuring the loss of protein-bound radioactivity in a filter-binding assay ${ }^{1}$.

Mass spectrometric analysis. All electrospray experiments were done on a triple quadrupole instrument (API III, Perkin-Elmer). CNFI-exposed and untreated RhoA were desalted on a $100 \mathrm{nl}$ RI Poros microcolumn as described ${ }^{22}$. They were eluted in $2 \times 0.5 \mu \mathrm{l} 50 \%$ acetonitrile, $5 \%$ formic acid into a nano electrospray spraying needle for mass spectrometry.

The proteins were digested with trypsin (Boehringer Mannheim, sequencing grade) for $5 \mathrm{~h}$. The peptide mixture was step-eluted with $2 \times 0.4 \mu \mathrm{l} 50 \%$ methanol, $5 \%$ formic acid into the emitter of the nano electrospray ion source.

Received 14 March; accepted 17 April 1997.

Paterson, H. F. Microinjection of recombinant $\mathrm{p} 21^{\text {rho }}$ induces rapid changes in cell morphology. J. Cell Biol. 111, 1001-1007 (1990)

. Machesky, L. M. \& Hall, A. Rho: A connection between membrane receptor signalling and the cytoskeleton. Trends Cell Biol. 6, 304-310 (1996).

Lim, L., Manser, E., Leung, T. \& Hall, C. Regulation of phosphorylation pathways by p21 GTPasesthe p21 Ras-related Rho subfamily and its role in phosphorylation signalling pathways. Eur. J. Biochem. 242, 171-185 (1996).

4. Just, I. et al. Glucosylation of Rho proteins by Clostridium difficile toxin B. Nature 375, 500-503 (1995)

Oswald, E. et al. Cytotoxic necrotizing factor type 2 produced by virulent Escherichia coli modifies the small GTP-binding proteins Rho involved in assembly of actin stress fibers. Proc. Natl Acad. Sci. USA 91, 3814-3818 (1994)

6. Fiorentini, C. et al. Escherichia coli cytotoxic necrotizing factor 1: Evidence for induction of actin assembly by constitutive activation of the p21 Rho GTPase. Infect. Immun. 63, 3936-3944 (1995). Caprioli, A., Falbo, V., Roda, L. G., Ruggeri, F. M. \& Zona, C. Partial purification and characterization of an Escherichia coli toxic factor that induces morphological cell alterations. Infect. Immun. 39, 1300 1306 (1983).

8. de Rycke, J. et al. Evidence for two types of cytotoxic necrotizing factor in human and animal clinical isolates of Escherichia coli. J. Clin. Microbiol. 28, 694-699 (1990).

Falzano, L. et al. Induction of phagocytic behaviour in human epithelial cells by Escherichia coli cytotoxic necrotizing factor type 1. Mol. Microbiol. 9, 1247-1254 (1993).

10. Leonard, D. A., Evans, T., Hart, M., Cerione, R. A. \& Manor, D. Investigation of the GTP-binding/ GTPase cycle of Cdc42Hs using fluorescence spectroscopy. Biochemistry 33, 12323-12328 (1994).

11. Ridley, A. J. Microinjection of Rho and Rac into quiescent Swiss 3T3 cells. Methods Enzymol. 256, 313-320 (1995).

12. Diekmann, D. \& Hall, A. In vitro binding assay for interactions of Rho and Rac with GTPase-activating proteins and effectors. Methods Enzymol. 256, 207-215 (1995).

13. Renshaw, M. W., Toksoz, D. \& Schwartz, M. A. Involvement of the small GTPase Rho in integrinmediated activation of mitogen-activated protein kinase. J. Biol. Chem. 271, 21691-21694 (1996).

14. Der, C. J., Finkel, T. \& Cooper, G. M. Biological and biochemical properties of human $\mathrm{ras}^{\mathrm{H}}$ genes mutated at codon 61. Cell 44, 167-176 (1986).

15. Schweins, T. et al. Substrate-assisted catalysis as a mechanism for GTP hydrolysis of $\mathrm{p} 21^{\text {ras }}$ and other GTP-binding proteins. Nature Struct. Biol. 2, 36-44 (1995).

16. Just, I. et al. Clostridium difficile toxin B acts on the GTP-binding protein Rho. J. Biol. Chem. 269, 10706-10712 (1994)

17. Hiratsuka, T. New ribose-modified fluorescent analogs of adenine and guanine nucleotides available as substrates for various enzymes. Biochim. Biophys. Acta 742, 496-508 (1983).

18. Falbo, V., Pace, T., Picci, L., Pizzi, E. \& Caprioli, A. Isolation and nucleotide sequence of the gene encoding cytotoxic necrotizing factor 1 of Escherichia coli. Infect. Immun. 61, 4909-4914 (1993).

19. Aktories, K. \& Just, I. In vitro ADP-ribosylation of Rho by bacterial ADP-ribosyltransferases. Methods Enzymol. 256, 184-195 (1995).

20. Just, I., Selzer, J., Von Eichel-Streiber, C. \& Aktories, K. The low molecular mass GTP-binding protein Rho is affected by toxin A from Clostridium difficile. J. Clin. Invest. 95, 1026-1031 (1995).

21. Horiguchi, Y., Senda, T., Sugimoto, N., Katahira, J. \& Matsuda, M. Bordetella bronchiseptica dermonecrotizing toxin stimulates assembly of actin stress fibers and focal adhesions by modifying the small GTP-binding protein rho. J. Cell Sci. 108, 3243-3251 (1995).

22. Wilm, M. \& Mann, M. Analytical properties of the nanoelectrospray ion source. Anal. Chem. 68, 1-8 (1996).

Acknowledgements. We thank I. Just for critical reading of the manuscript.

Correspondence and requests for materials should be addressed to K.A. (e-mail: aktories@ruf.unifreiburg.de).

\section{Toxin-induced activation of the G protein p21 Rho by deamidation of glutamine}

\section{Gilles Flatau*, Emmanuel Lemichez*, Michel Gauthier*, Pierre Chardin $\uparrow$, Sonia Paris $\nmid$, Carla Fiorentini $\ddagger$ \& Patrice Boquet*}

* INSERM U452, Faculté de Médecine, avenue de Valombrose, Nice 06107,

Cedex 2, France

$\dagger$ Institut de Pharmacologie Moléculaire et Cellulaire du CNRS, route des Lucioles, Sophia Antipolis, Valbonne 06560, France

$\ddagger$ Department of Ultrastructures, Istituto Superiore di Sanità, viale Regina Elena, 00161, Roma, Italy

Pathogenic Escherichia coli are responsible for a variety of diseases, including diarrhoea, haemolytic uraemic syndrome, kidney infection, septicaemia, pneumonia and meningitis. Toxins called cytotoxic necrotizing factors (CNFs) are among the virulence factors produced by uropathogenic $(\mathrm{CNF} 1)^{1}$ or enteropathogenic $(\mathrm{CNF} 2)^{2}$ E. coli strains that cause diseases in humans and animals, respectively. CNFs induce an increase in the content of actin stress fibres and focal contacts in cultured cells ${ }^{3,4}$. Effects of CNFs on the actin cytoskeleton correlated with a decrease in the electrophoretic mobility of the GTP-binding protein $\mathrm{Rho}^{4,5}$ and indirect evidence indicates that CNF1 might constitutively activate Rho $^{6}$. Here we show that CNF1 catalyses the deamidation of a glutamine residue at position 63 of Rho, turning it into glutamic acid, which inhibits both intrinsic GTP hydrolysis and that stimulated by its GTPaseactivating protein (GAP). Thus, this deamidation of glutamine 63 by CNF1 leads to the constitutive activation of Rho, and induces the reorganization of actin stress fibres. To our knowledge, CNF1 is the first example of a bacterial toxin acting by deamidation of a specific target protein.

Incubation of Vero cells with CNF1 induces actin stress fibre accumulation and cell spreading (Fig. 1a, b), with a concomitant decrease in the electrophoretic mobility of the Rho protein on SDSPAGE (Fig. 1c). Incubation of recombinant RhoA with purified CNF1 in vitro gives the same mobility shift as that observed after in vivo treatment (Fig. 2). This result indicates that CNF1 directly modifies Rho without the need for cellular cofactors. Incubation with CNF1 did not modify the electrophoretic mobilities of Rac, Cdc42, Rab6 or Ras either in vivo or in vitro (data not shown). In vitro induction of the mobility shift by CNF1 was blocked by heat denaturation of either RhoA or CNF1 (Fig. 2). To analyse the modification induced by CNF1, we eluted RhoA treated with CNF1 in vitro, untreated RhoA, or a mixture of both from gels and digested the eluate with trypsin. Separation of the tryptic peptides on a DEAE C-18 HPLC column yielded three major peptides (A,B,C); peptide B in CNF1-treated RhoA eluted slightly later than peptide B from untreated RhoA (Fig. 3a, top and middle panels). In the sample containing both CNF1-treated and untreated RhoA, peptide B is duplicated (Fig. 3a, lower panel). Peptide B1 elutes as peptide B from the untreated RhoA sample, whereas peptide B2 elutes as peptide B from CNF1-treated RhoA (Fig. 3a). Amino-acid sequencing of peptide $B$ from untreated RhoA yielded the sequence QVELALWDTAGQEDYDR, corresponding to amino acids 52-68 of $\mathrm{RhoA}^{7}$, whereas in CNF1-treated RhoA the sequence was QVELALWDTAGEEDYDR, which differs only by having a glutamic acid residue at position 63 instead of glutamine. Accordingly, in the CNF1-treated and untreated RhoA mixture, the aminoacid sequence of the B1 peptide corresponded exactly to RhoA 5268 , whereas the B2 peptide had the single Q63E modification of CNF1-treated RhoA. Apart from Gln 63, RhoA contains two additional glutamine residues in positions 29 and 52 (ref. 7) which were 


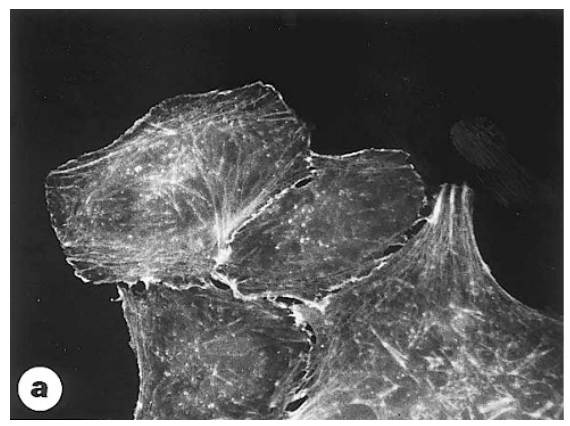

Figure 1 Induction of actin stress fibres in Vero cells by CNF1 and modification of the electrophoretic mobility of the Rho GTP-binding protein by CNF1 in vivo. a, b Vero cells were treated with $10^{-10} \mathrm{M}$ CNF1 for $18 \mathrm{~h}$, fixed with $4 \%$ paraformalde-

Figure 2 CNF1-induced mobility-shifting of RhoA in vitro. RhoA was incubated with CNF1 and processed for electrophoresis. As a control, RhoA or CNF1 was denaturated by treatment at $95^{\circ} \mathrm{C}$ for $15 \mathrm{~min}$, then incubated with either native CNF1 or RhoA.

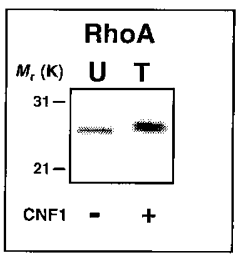

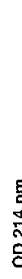

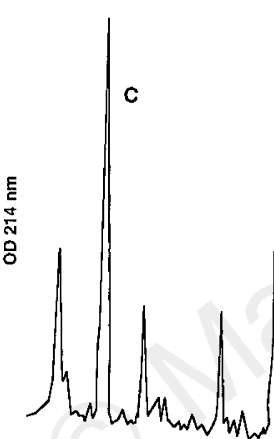

QUELALWDTAGQ63EDYDR<smiles>C1=CCCCC1</smiles>

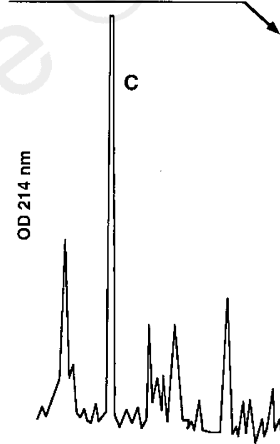

QUELALWDTAGEG3EOYDR

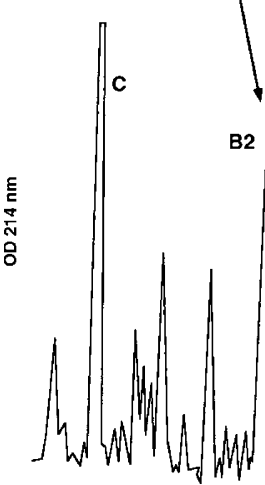

H
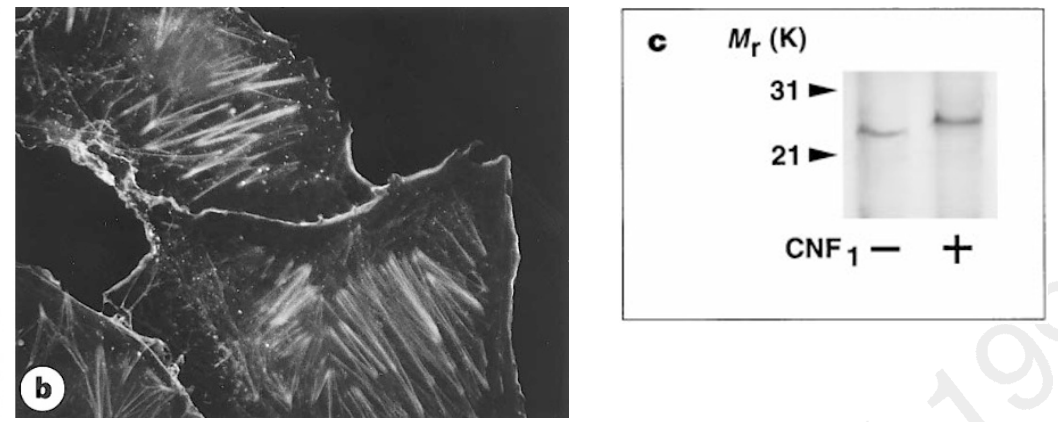

hyde, permeabilized with $0.05 \%$ Triton X-100 and then stained for F-actin with FITC-phalloidin. a, Control cells; b, cells incubated with CNF1. c, Mobility-shift of Rho in control and CNF1-treated Vero cells.

$$
M_{\mathrm{r}}(\mathrm{K})
$$

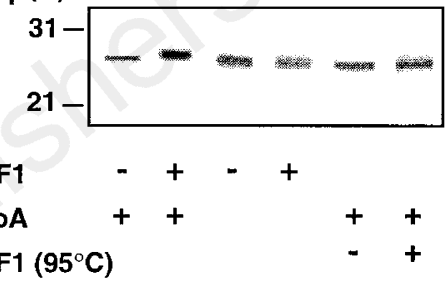

RhoA $\left(95^{\circ} \mathrm{C}\right)++$

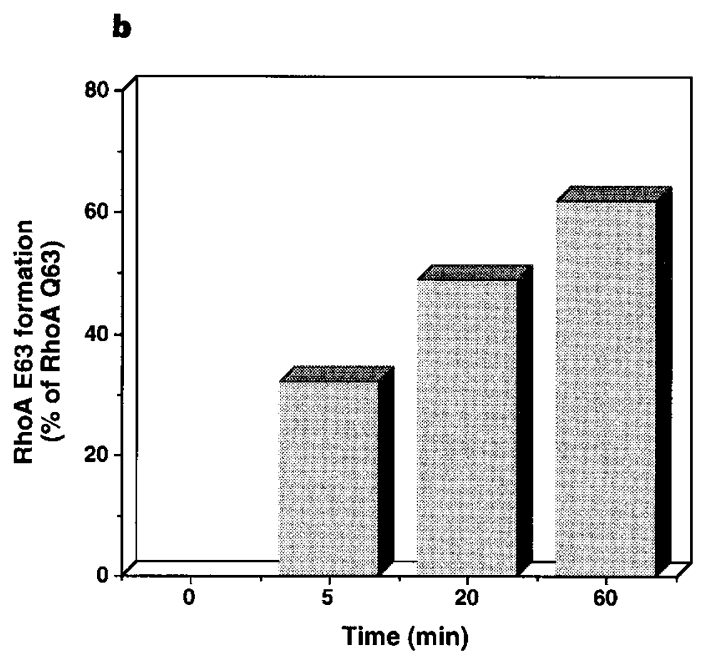

$\mathbf{U}+\mathbf{T}$

Figure 3 Deamidation of Rho glutamine 63 by CNF1. a, Peptide chromatograms of RhoA incubated with ( $T$ ) or without (U) CNF1, and of a mixture of both $(U+T)$. The amino-acid sequence of the RhoA tryptic peptide spanning amino acids 52-68 is indicated by arrows. Arrowhead indicates the direction of peptides elution. $\mathbf{b}$, Time course of CNF1 deamidase effect on RhoA, as studied by formation of peptide 52-68 of RhoA with glutamic acid at position 63 . 
a
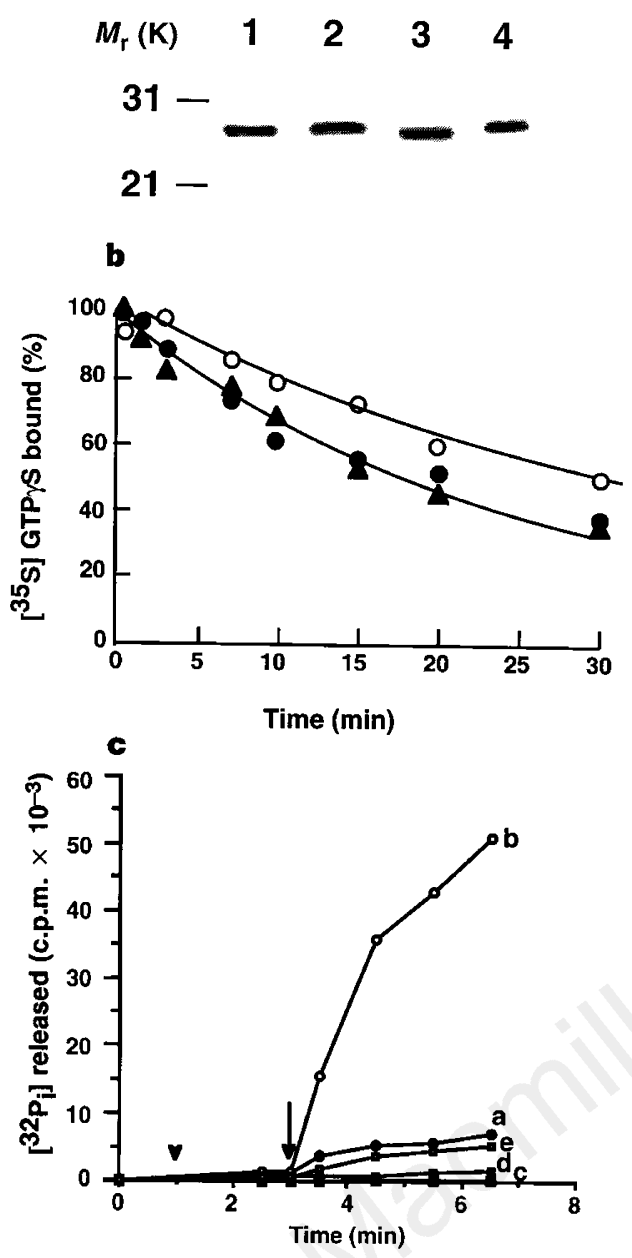

Figure 4 Electrophoretic mobility shift, time course of $\left[{ }^{35} \mathrm{~S}\right] \mathrm{GTP}-\gamma \mathrm{S}$ dissociation, and determination of the intrinsic and rhoGAP-stimulated GTP hydrolysis of RhoA wild type, Q63E RhoA, and CNF1-treated RhoA. a, Electrophoretic mobilities of: 1, RhoA; 2, CNF1-treated RhoA; 3, RhoA; 4, Q63E RhoA. b, Dissociation of [ ${ }^{35}$ S] GTP$\gamma \mathrm{S}$ in $1 \mathrm{mM} \mathrm{MgCl}$ from RhoA (white circles) Q63E RhoA (black circles) and CNF1treated RhoA (triangles). c, Time course of intrinsic and rhoGAP-stimulated GTP hydrolysis. Reactions are described in Methods. Equal loading of the different GTP-binding proteins with [ $\left.{ }^{32} \mathrm{P}\right]$ GTP was verified by filtration, as described for the dissociation assay. $\mathrm{MgCl}_{2}$ was added $1 \mathrm{~min}$ after the onset of the reaction to initiate GTP hydrolysis (arrowhead). GST-rhoGAP was added 3 min after the onset of the reaction (arrow); final concentration, $10 \mathrm{nM}$. Line a, RhoA minus rhoGAP; line b, RhoA plus rhoGAP; line c, Q63E RhoA plus or minus rhoGAP; line d, CNF1-treated RhoA minus rhoGAP; line e, CNF1-treated RhoA plus rhoGAP. Results are given in c.p.m. of free ${ }^{32} \mathrm{P}_{\mathrm{i}}$. Times are shown in minutes after the start of the reaction.

not modified by treatment with CNF1. Thus, CNF1 acts as a deamidase that specifically modifies Gln 63 of Rho to glutamic acid.

CNF1 must work enzymatically on Rho because the mobility shift induced by CNF1 is blocked by heat denaturation of Rho or of CNF1 (Fig. 2), and because the amount of Q63E RhoA formed depends on the incubation time of Rho with CNF1 (Fig. 3b). Rho deamidation in vitro is relatively slow, with only $60 \%$ of Q63 RhoA being converted after $1 \mathrm{~h}$ (Fig. 3b). It is known that cells need to be incubated with CNF1 for a relatively long time before actin stress fibres accumulate and cell spreading is $\operatorname{seen}^{3,4,6}$. The kinetics of deamidation by CNF1 of Rho in vitro were not significantly affected by including cytosolic factors or altering our reaction. Mutations at position 61 of Ras (corresponding to Rho position 63) also modify its apparent electrophoretic mobility ${ }^{8,9}$.

We next studied the effects of CNF1 on the rate of nucleotide dissociation, the rate of intrinsic GTP hydrolysis, and the rate of GTP hydrolysis stimulated by the Rho GTPase-activating protein (rhoGAP) $)^{10}$, and compared them with those of a Q63E RhoA mutant. The electrophoretic mobility of Q63E RhoA was identical to CNF1modified RhoA (Fig. 4a). Dissociation of GTP- $\gamma \mathrm{S}$ at $1 \mathrm{mM} \mathrm{Mg}^{2+}$ from both CNF1-treated RhoA and mutated Q63E RhoA was slightly increased compared to RhoA (Fig. $4 \mathrm{~b}$ ), with the GTP- $\gamma \mathrm{S}$ 'off' rate being $k=0.04 \mathrm{~min}^{-1}$ for both CNF1-modified RhoA and Q63E RhoA, and $0.023 \mathrm{~min}^{-1}$ for unmodified RhoA. rhoGAP-stimulated GTP hydrolysis was abolished on Q63E RhoA compared with unmodified RhoA (Fig. 4c). A small residual activity could be detected on CNF1treated RhoA (Fig. 4c), probably due to the presence of trace amounts of unmodified RhoA. The intrinsic GTPase activity was also lost in the mutant (Fig. 4c). CNF1-modified RhoA and the Q63E mutant have comparable nucleotide affinities and both lack GTPase activity, indicating that they could be identical.

To show that CNF1-treated RhoA and Q63E RhoA behave as activated forms of RhoA, we microinjected both into Vero cells. As wild-type RhoA can induce stress fibres at concentrations close to those required by the permanently active form of RhoA, V14 RhoA ${ }^{11}$, we determined the minimum concentrations of RhoA, CNF1-modified RhoA and Q63E RhoA needed to induce formation of actin stress fibres as a result of microinjection into Vero cells. Microinjection of Vero cells with RhoA at $50 \mu \mathrm{g} \mathrm{ml}^{-1}$ induced maximal stress fibre formation (Fig. 5a), but at $10 \mu \mathrm{g} \mathrm{ml}^{-1}$ there was no effect (Fig. 5b). CNF1-modified RhoA (Fig. 5c, d) or Q63E RhoA (Fig. 5e, f) had maximal effect at $25 \mu \mathrm{g} \mathrm{ml}^{-1}$ and at $10 \mu \mathrm{g} \mathrm{ml}^{-1}$ these effects were still evident (Fig. 5d, f). Thus, CNF1-modified RhoA and Q63E RhoA are both equally effective at inducing the formation of stress fibres. Our results show that CNF1 activates Rho by deamidating Gln 63 to glutamic acid, thereby impairing the intrinsic and rhoGAP-stimulated GTPase. CNF1-modified Rho behaves as the other constitutively active forms of Rho that are mutated at residues 14 or 63 .

The Rho family proteins play a key role in actin remodelling in response to growth factors ${ }^{12}$. In Swiss 3T3 cells Rho controls actin reorganization into stress fibres and the formation of focal contacts $^{13}$, Rac regulates membrane ruffling ${ }^{14}$, and Cdc42 is responsible for the formation of filopodia ${ }^{15}$. We have previously shown that CNF1 induces a phagocytic behaviour through activation of membrane ruffling in HEp-2 cells ${ }^{16}$. We have now shown that in Vero cells CNF1 induces actin stress fibres but not ruffling (Fig. 1) and decreases the electrophoretic mobility of Rho but not of Rac or Cdc42 (although we cannot rule out the possibility that the PAGE system might not resolve the CNF1-modified forms of Rac and Cdc42). Membrane ruffling may be induced by Rho (in addition to Rac) only in some cell types such as HEp-2 or KB cells when they are stimulated by hepatocyte growth factor or phorbol esters ${ }^{17}$. We and others have shown that the invasive bacterium Shigella flexneri enters HeLa cells as a result of membrane ruffling triggered by $\mathrm{Rho}^{18,19}$. The dermonecrotic toxin from Bordetella bronchiseptica $(\mathrm{DNT})^{20}$, which shares amino-acid sequence homology with CNF1 (ref. 21), also promotes actin reorganization in cultured cells ${ }^{22}$. Furthermore, DNT induces a mobility shift of Rho $^{22}$, suggesting that it also deamidates Gln 63 of Rho. Enzymatic deamidation is a previously undescribed activity of bacterial toxins acting inside host cells; others include ADP-ribosylation, depurination, adenylate cycling, metal-dependent proteolysis and glycosylation. We have now demonstrated that the deamidase activity of CNF1 is responsible for the cytopathic effects of this toxin, and it is likely that this modification is used by other microbial or eukaryotic cell factors to modify regulatory proteins in host cells.

\section{Methods}

Rho electrophoretic mobility-shift assay. Highly purified $\mathrm{CNF}^{16}$ was used. Recombinant RhoA was made from the pGEX 2T GST-F25N RhoA plasmid ${ }^{23}$ (gift from A. Hall). The GST-RhoA fusion protein was cleaved by thrombin 

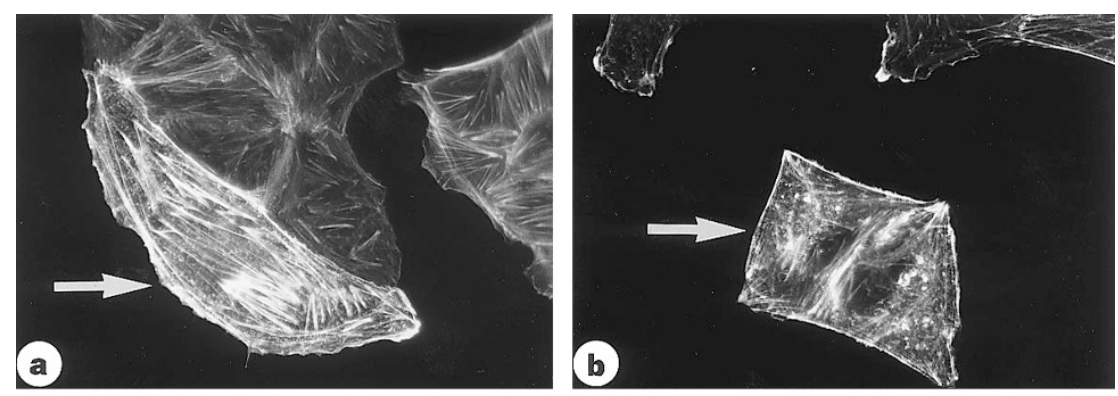

Figure 5 Microinjection into Vero cells of CNF1-treated RhoA, Q63E RhoA and RhoA. a, b, Cells microinjected with RhoA (50 $\mathrm{g} \mathrm{ml}^{-1}$ in $\mathbf{a} ; 10 \mu \mathrm{g} \mathrm{ml}^{-1}$ in b). c, d, Cells microinjected with CNF1-treated RhoA (c, $25 \mu \mathrm{g} \mathrm{ml}^{-1}$; d, $10 \mu \mathrm{g} \mathrm{ml}^{-1}$ ). e, f, Cells microinjected with Q63E RhoA (e, $25 \mathrm{~g} \mathrm{ml}^{-1} ; \mathbf{f}, 10 \mu \mathrm{g} \mathrm{ml}^{-1}$ ). Arrows, microinjected cells. Scale bar, $10 \mu \mathrm{m}$.
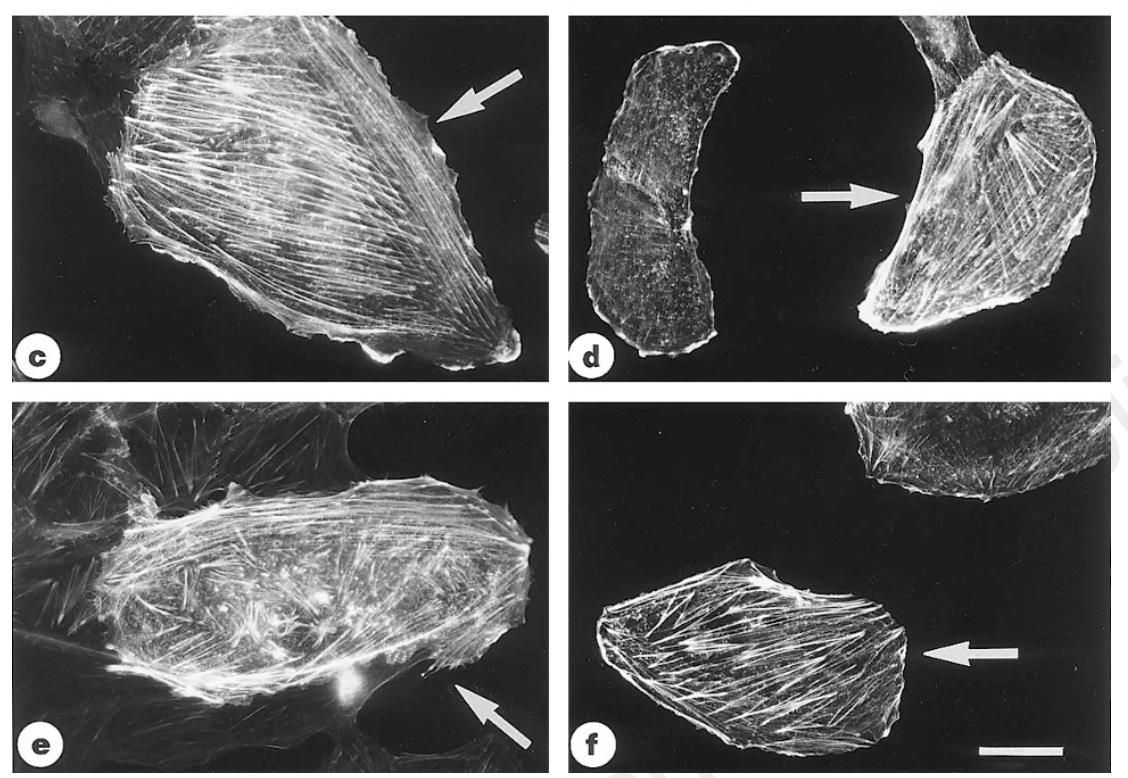

and incubated for $2 \mathrm{~h}$ at $37^{\circ} \mathrm{C}(0.5 \mu \mathrm{g}$ CNF1 for $2 \mu \mathrm{g}$ RhoA $)$ in $20 \mathrm{mM}$ Tris-HCl buffer, $\mathrm{pH} 7.5$, containing $1 \mathrm{mM} \mathrm{MgCl}, 10 \mathrm{mM}$ dithiothreitol (DTT) and $100 \mu \mathrm{M}$ GDP. Samples were boiled for $1 \mathrm{~min}$, electrophoresed on 12\% SDSpolyacrylamide gels and stained with Coomassie blue.

Trypsin digestion of gel-eluted Rho, peptide separation and amino-acid sequencing. RhoA was incubated for $2 \mathrm{~h}$ at $37^{\circ} \mathrm{C}$ with CNF1 $(0.5 \mu \mathrm{g}$ CNF1 for $2 \mu \mathrm{g}$ RhoA) in $20 \mathrm{mM}$ Tris- $\mathrm{HCl}$ buffer, $\mathrm{pH} 7.5$, containing $1 \mathrm{mM} \mathrm{MgCl}_{2}$, $10 \mathrm{mM}$ DTT and $100 \mu \mathrm{M}$ GDP, and electrophoresed on a $12 \%$ SDS-polyacrylamide gel which was stained with amido-black. Bands corresponding to the Rho protein were cut out of the gel, eluted and digested with $1 \mu \mathrm{g}$ trypsin in $200 \mu \mathrm{l} 100 \mathrm{mM}$ Tris- $\mathrm{HCl}$ buffer (pH 8.8) containing $0.01 \%$ Tween 20 , for $18 \mathrm{~h}$ at $35^{\circ} \mathrm{C}$. Tryptic peptides were separated by HPLC on a DEAE-C18 column using an acetonitrile/trifluoracetic acid gradient. Peptides were sequenced using an Applied Biosystems microsequencer.

Preparation of the Q63E RhoA mutant. The Q63E mutation was introduced by polymerase chain reaction (PCR) and the plasmid checked by sequencing. Q63E RhoA was expressed in E. coli as a GST fusion protein which was then cleaved by thrombin.

GTP- $\gamma$ S dissociation assay. Q63 RhoA, CNF1-treated RhoA and Q63E RhoA ( $1 \mu \mathrm{M}$ final) were loaded with $25 \mu \mathrm{M}\left[{ }^{35} \mathrm{~S}\right] \mathrm{GTP}-\gamma \mathrm{S}$ in a low-magnesium buffer (50 mM Tris-HCl, pH 7.5, $100 \mathrm{mM} \mathrm{KCl}, 1 \mathrm{mM}$ DTT, $1 \mathrm{mM} \mathrm{MgCl}_{2}$, and $2 \mathrm{mM}$ EDTA) at $37^{\circ} \mathrm{C}$ for $1 \mathrm{~min}$. The final concentration of free $\mathrm{Mg}^{2+}$ was adjusted to $1 \mathrm{mM}$ and $1 \mathrm{mM}$ GTP- $\gamma S$ was added to initiate $\left[{ }^{35} \mathrm{~S}\right] \mathrm{GTP}-\gamma \mathrm{S}$ dissociation. Samples of $25 \mu \mathrm{l}$ were filtered at the indicated times and radioactivity counted ${ }^{24}$. GTPase assay. Q63 RhoA, CNF1-treated RhoA and Q63E RhoA (1 $\mu \mathrm{M}$ final) were loaded with $25 \mu \mathrm{M}\left[\gamma^{-}{ }^{32} \mathrm{P}\right] \mathrm{GTP}$ as described for $\left[{ }^{35} \mathrm{~S}\right] \mathrm{GTP}-\gamma \mathrm{S} . \mathrm{MgCl}_{2}$ $\left(1 \mathrm{mM}\right.$ free $\mathrm{Mg}^{2+}$ ) was added to start the intrinsic GTPase. For measurements of rhoGAP-stimulated GTP hydrolysis, $10 \mathrm{nM}$ of a 30K C-terminal fragment of GST-rhoGAP (gift from A. Hall ${ }^{25}$ ) was added 2 min after $\mathrm{MgCl}_{2}$. At the indicated times, aliquots of $25 \mu \mathrm{l}$ were removed and the ${ }^{32} \mathrm{P}_{\mathrm{i}}$ release was measured by the charcoal method ${ }^{26}$.

Cell microinjection, immunofluorescence and ADP-ribosylation of Rho. F25N RhoA ${ }^{23}$ was used as it is threefold more potent, upon microinjection, in inducing stress fibres than F25 RhoA ${ }^{15}$. CNF1 $(12 \mu \mathrm{g})$ was incubated with $50 \mu \mathrm{g}$ recombinant GST-RhoA bound to glutathione beads (Sigma) for $1 \mathrm{~h}$ at $37^{\circ} \mathrm{C}$ in $50 \mathrm{mM}$ Tris- $\mathrm{HCl}$ buffer, $\mathrm{pH} 7.5$, containing $5 \mathrm{mM} \mathrm{MgCl} 2,50 \mathrm{mM} \mathrm{NaCl}$, $10 \mathrm{mM}$ DTT, $150 \mathrm{mM} \mathrm{KCl}$ (buffer A) supplemented with $100 \mu \mathrm{M}$ GDP (final volume, $1 \mathrm{ml}$ ). The mixture was then packed into a mini-column which was washed with $30 \mathrm{ml}$ buffer A. GST-RhoA was eluted from the glutathione beads with buffer A containing $20 \mathrm{mM}$ reduced glutathione, in $100 \mu \mathrm{l}$ (containing $0.5 \mathrm{mg} \mathrm{ml}^{-1} \mathrm{GST}-\mathrm{RhoA}$ ) and tested for CNF1-induced mobility shift by SDSPAGE. GST-RhoA $(100 \mu l)$ was cleaved with $1 \mu \mathrm{l}$ thrombin $\left(1 \mathrm{U}^{-1}\right)$ (Sigma) for $1 \mathrm{~h}$ at room temperature then dialysed against $50 \mathrm{mM}$ Tris- $\mathrm{HCl}$ buffer, $\mathrm{pH}$ 7.5 , containing $5 \mathrm{mM} \mathrm{MgCl}, 150 \mathrm{mM} \mathrm{KCl}, 0.1 \mathrm{mM}$ DTT (microinjection buffer (MB)) to remove glutathione. GST was then separated from Rho by binding to glutathione beads and incubating with $10 \mu \mathrm{l} p$-aminobenzamidine beads (Sigma) to remove thrombin. Before microinjection, the concentration of active GTP-binding proteins present in the RhoA, RhoA Q63E and CNF1modified RhoA preparations was determined by binding to $\left[{ }^{35} \mathrm{~S}\right] \mathrm{GTP}-\gamma \mathrm{S}$ as described ${ }^{24}$. Preparations of the different GTPases were found to be $60 \%$ active. RhoA or Q63E RhoA was diluted with protein A-purified rabbit non-immune antibodies $\left(0.5 \mathrm{mg} \mathrm{ml}^{-1}\right)$ (to determine the efficiency of microinjection) in MB (final volume $20 \mu \mathrm{l}$ ) and microinjected (Transjector 5246 system, Eppendorf) into serum-starved $(0.2 \%$ FCS, overnight) Vero cells. Microinjections were done in DMEM, which contained $25 \mathrm{mM}$ HEPES buffer to maintain the $\mathrm{pH}$ at 7.3. Cells were then incubated at $37^{\circ} \mathrm{C}$ for $20 \mathrm{~min}$, fixed with $4 \%$ paraformaldehyde, processed for F-actin immunofluorescence with FITC-phalloidin together with rhodamine-labelled anti-rabbit antibodies (Amersham) and examined and photographed with a fluorescence-equipped photomicroscope.

Semi-confluent Vero cells $\left(2 \times 10^{6}\right)$ were incubated or not with $10^{-10} \mathrm{M}$ $\mathrm{CNF} 1$ for $18 \mathrm{~h}$ then lysed, and lysates were radioactively ADP-ribosylated with C. botulinum exoenzyme $\mathrm{C}_{3}$ as described ${ }^{27}$.

Received 14 March; accepted 17 April 1997.

1. Caprioli, A., Falbo, V., Roda, L. G., Ruggeri, F. M. \& Zona, C. Partial purification and characterization of an Escherichia coli toxic factor that induces morphological alterations. Infect. Immun. 39, 13001306 (1983). 
2. De Rycke, J. et al. Evidence for two types of cytotoxic necrotizing factor in human and animal clinical isolates. J. Clin. Microbiol. 28, 694-699 (1990).

Fiorentini, C. et al. Cytoskeletal changes induced in HEp-2 cells by the cytotoxic necrotizing factor of Escherichia coli. Toxicon 26, 1047-1056 (1988).

4. Oswald, E. et al. Cytotoxic necrotizing factor type 2 produced by virulent Escherichia coli modifies the small GTP-binding proteins Rho involved in assembly of actin stress fibers. Proc. Natl Acad. Sci. USA 91, 3814-3818 (1994).

Fiorentini, C. et al. Escherichia coli cytotoxic necrotizing factor 1 increases actin assembly via the $\mathrm{p} 21$ Rho protein. P. Zbl. Bakt. (suppl.) 24, 404-405 (1994).

6. Fiorentini, C. et al. Escherichia coli cytotoxic necrotizing factor 1: evidence for induction of actin assembly by constitutive activation of the p21 Rho GTPase. Infect. Immun. 63, 3936-3944 (1995) Yeramian, P., Chardin, P., Madaule, P. \& Tavitian, A. Nucleotide sequence of human Rho cDNA clone 12. Nucleic Acids Res. 15, 1869 (1987).

8. Der, C. J., Finkel, T. \& Cooper, G. M. Biological and biochemical properties of human ras H genes mutated at codon 61. Cell 44, 167-176 (1986).

Srivastava, S. K., Yuasa, Y., Reynolds, S. H. \& Aaronson, S. A. Effects of two major activating lesions on the structure and conformation of human Ras oncogene products. Proc. Natl Acad. Sci. USA 82, 38 42 (1985).

10. Garrett, M. D., Major, G. N., Totty, N. \& Hall, A. Purification and N-terminal sequence of the 21 Rho GTPase activating protein RhoGAP. Biochem. J. 276, 833-836 (1991).

11. Ridley, A. J. Microinjection of Rho and Rac into quiescent swiss 3 T3 cells. Methods Enzymol. 256, 313 320 (1995).

12. Machesky, L. M. \& Hall, A. Rho: a connection between membrane receptor signalling and the cytoskeleton. Trends Cell Biol. 6, 304-310 (1996).

13. Ridley, A. J. \& Hall, A. The small GTP-binding protein Rho regulates the assembly of focal adhesions and actin stress fibers in response to growth factors. Cell 70, 389-400 (1992).

14. Ridley, A. J., Paterson, H. F., Johnston, C. L., Diekmann, D. \& Hall, A. The small GTP-binding protein Rac regulates growth factor-induced membrane ruffling. Cell 70, 401-410 (1992).

15. Nobes, C. D. \& Hall, A. Rho, Rac and Cdc42 GTPases regulate the assembly of multimolecular complexes associated with actin stress fibers, lamellipodia and filopodia. Cell 81, 53-62 (1995).

16. Falzano, L. et al. Induction of phagocytic behaviour in human epithelial cells by Escherichia coli cytotoxic necrotizing factor type 1. Mol. Microbiol. 9, 1247-1254 (1993).

17. Nishiyama, T. et al. Rac p 21 is involved in insulin-induced membrane ruffling and Rho p 21 is involved in hepatocyte growth factor-and 12-O-tetradecanoylphorbol-13 acetate (TPA)-induced membrane ruffling in KB cells. Mol. Cell. Biol. 14, 2447-2456 (1994).

18. Adam, T., Giry, M., Boquet, P. \& Sansonetti, P. Rho-dependent membrane folding causes Shigella entry into cells. $E M B O \mathrm{~J} .15,3315-3321$ (1996).

19. Watarai, M., Kamata, Y., Kozaki, S. \& Sasakawa, C. Rho, a small GTP-binding protein, is essential for Shigella invasion of epithelial cells. J. Exp. Med. 185, 281-292 (1997).

20. Walker, K. E. \& Weiss, A. Characterization of the dermonecrotic toxin in members of the genus Bordetella. Infect. Immun. 62, 3817-3828 (1994).

21. Falbo, V., Pace, T., Picci, L., Pizzi, E. \& Caprioli, A. Isolation and nucleotide sequence of the gene encoding cytotoxic necrotizing factor 1 of Escherichia coli. Infect. Immun. 61, 4909-4914 (1993).

22. Horiguchi, Y., Senda, T., Sugimoto, N., Katahira, J. \& Matsuda, M. Bordetella bronchiseptica dermonecrotizing toxin stimulates assembly of actin stress fibers and focal adhesion points by modifying the small GTP-binding protein Rho. J. Cell Sci. 108, 3243-3251 (1995)

23. Self, A. J. \& Hall, A. Purification of recombinant Rho/Rac/G25K from Escherichia coli. Method Enzymol. 256, 3-10 (1995)

24. Franco, M., Chardin, P., Chabre, M. \& Paris, S. Myristoylation of ADP-ribosylation factor 1 facilitates nucleotide exchange at physiological $\mathrm{Mg}^{2+}$ levels. J. Biol. Chem. 271, 1573-1578 (1996).

25. Self, A. J. \& Hall, A. Measurement of intrinsic nucleotide exchange and GTP hydrolysis rates. Method Enzymol. 256, 67-76 (1995)

26. Higashijima, T., Ferguson, K. M., Smigel, M. D. \& Gilman, A. G. The effect of GTP and $\mathrm{Mg}^{2+}$ on the GTPase activity and the fluorescent properties of $\mathrm{G}_{0}$. J. Biol. Chem. 262, 757-761 (1987).

27. Chardin, P. et al. The mammalian G-protein RhoC is ADP-ribosylated by Clostridium botulinum $\mathrm{C}_{3}$ and affects actin microfilaments in Vero cells. EMBO J. 8, 1087-1092 (1989).

Acknowledgements. We thank J. d'Alayer and M. Davi (Institut Pasteur, Paris, France) for trypsin digestion and amino-acid sequencing of Rho proteins; A. Hall for the gift of Rho and RhoGAP expression vectors; J. R. Murphy, E. Van Obberghen-Schilling. P. Cossart and A. Galmiche for discussion.

\section{A signature motif in transcriptional co-activators mediates binding to nuclear receptors}

\section{David M. Heery, Eric Kalkhoven, Susan Hoare \& Malcolm G. Parker}

Molecular Endocrinology Laboratory, Imperial Cancer Research Fund, 44 Lincoln's Inn Fields, London WC2A 3PX, UK

The binding of lipophilic hormones, retinoids and vitamins to members of the nuclear-receptor superfamily modifies the DNAbinding and transcriptional properties of these receptors, resulting in the activation or repression of target genes ${ }^{1,2}$. Ligand binding induces conformational changes in nuclear receptors and promotes their association with a diverse group of nuclear proteins, including SRC-1/p160 (refs 3-5), TIF-2/GRIP-1 (refs 6, 7) and $\mathrm{CBP} / \mathrm{p} 300$ (refs $4,5,8,9$ ) which function as co-activators of transcription, and RIP-140 (ref. 10), TIF-1 (ref. 11) and TRIP-1/ SUG-1 (refs 12,13) whose functions are unclear. Here we report that a short sequence motif LXXLL (where $L$ is leucine and $X$ is any amino acid) present in RIP-140, SRC-1 and CBP is necessary and sufficient to mediate the binding of these proteins to liganded nuclear receptors. We show that the ability of SRC-1 to bind the oestrogen receptor and enhance its transcriptional activity is dependent upon the integrity of the LXXLL motifs and on key hydrophobic residues in a conserved helix (helix 12) of the oestrogen receptor that are required for its ligand-induced activation function ${ }^{14}$. We propose that the LXXLL motif is a signature sequence that facilitates the interaction of different proteins with nuclear receptors, and is thus a defining feature of a new family of nuclear proteins.

We have previously shown that the nuclear protein RIP-140 $\left(M_{\mathrm{r}}\right.$ $140,000)$ interacts with nuclear receptors through at least two distinct sites located at the $\mathrm{N}$ and $\mathrm{C}$ termini of the protein ${ }^{15}$. To map these interaction sites, we examined fragments of RIP-140 fused with a heterologous DNA-binding domain (DBD) for interaction with nuclear receptors in a yeast two-hybrid system. By comparing the sequences of the shortest interacting fragments, we identified a short motif (LXXLL) that was present in all interacting fragments. In total, nine copies of the motif were identified in the RIP-140 sequence, but it was absent in fragments that had no binding activity. To determine whether these short sequences were sufficient to bind to nuclear receptors, we constructed a series of proteins consisting of a DBD fused to 8-10 amino acids which incorporated one copy of each of the nine LXXLL motifs. As shown in Fig. 1a, each of the nine motifs present in RIP-140 made a strong ligand-dependent interaction with the ligand-binding domain (LBD) of the oestrogen receptor (ER), whereas the DBD alone failed to bind. Results were comparable with the LBD of the retinoic acid receptor (RAR) (data not shown). Mutation of hydrophobic residues in the conserved helix $\mathrm{H} 12$, which abolishes its ligandinduced activation function (AF-2) and the recruitment of coactivators ${ }^{6,10,11,13}$, prevented the ligand-dependent interaction of all nine LXXLL motifs with ER (Fig. 1a). We conclude that a short conserved motif contained within as few as eight amino acids is sufficient to bind to transcriptionally active nuclear receptors.

Secondary structure analysis using the Phd program ${ }^{16}$ predicts that each motif in RIP-140 is $\alpha$-helical, with the conserved leucines forming a hydrophobic face. To determine the sequence constraints on functional interaction, we carried out a partial mutational analysis of one motif (amino acids 935-943; Fig. 1b). Western blot analysis indicated that there was no significant variation in the expression of the fusion proteins (data not shown). Mutation of valine at residue 935 to alanine gave $\sim 10$-fold reduction in reporter activity in the presence of ligand, which, as the first amino acid is hydrophobic in seven of the nine LXXLL motifs in RIP140, may indicate a preference for the hydrophobic residue at that position. Mutation of any one of the three conserved leucine residues L936, L939 or L940 to alanine resulted in a complete loss of binding to the LBD of ER (Fig. 1b) and RAR (data not shown), emphasizing their importance in mediating the interaction with nuclear receptors. In contrast, mutation to alanine of L941 (which is not conserved among the motifs; Fig. 2a), had no effect on the ability of this sequence to bind to the ER LBD. Replacement of a conserved leucine residue with a valine was tolerated at L936, but not at L939 or L940, indicating that hydrophobic character alone is not sufficient to maintain interaction with ER (Fig. 1b). Amino acids K937, Q938, S942 and E943 were not subjected to mutagenesis as they are not conserved among the motifs we have identified (Fig. 2a).

The steroid receptor co-activator SRC-1 is a truncated protein which interacts with the progesterone receptor through a 196amino-acid C-terminal region ${ }^{3}$. We found that the eight most Cterminal amino acids fit the LXXLL consensus, and indeed this 
sequence (DBD-SRC1a 1,434-1,442) showed strong ligandinduced binding to ER, but not to the ER H12 mutant (Fig. 1a). Full-length SRC-1 (SRC-1a) proteins from mouse (1,459 amino acids $)^{4,5}$ and human $(1,441$ amino acids; E.K. et al., manuscript in preparation) an additional nuclear-receptor interaction region between residues 569 and 789 (ref. 5) and 570 and 780, respectively (E.K. et al., manuscript in preparation). Three copies of the LXXLL motif were identified in this central interaction domain of human SRC-1a (Fig. 2a), each of which bound in a ligand-dependent manner to both ER (Fig. 1a) and RAR (data not shown), but not the ER H12 mutant. Interestingly, the sequences and relative positions of the three motifs in the central domain of SRC-1a are conserved in the related co-activator protein TIF-2 (transcriptional intermediary factor 2) (Fig. 2a,b), and correspond to the region of TIF-2 that binds to nuclear receptors ${ }^{6}$. However, unlike SRC-1a, TIF-2 lacks a motif at its $\mathrm{C}$ terminus. In addition, we noted that SRC-1 contains three other sequences matching the LXXLL consensus. The motif at residues $45-53$, within the basic helix-loophelix domain at the $\mathrm{N}$ terminus of SRC- $1 \mathrm{a}^{5}$, is predicted by the Phd program to be $\alpha$-helical, but interacts only very weakly (sixfold) with liganded ER (Fig. 1a) or RAR (not shown), which is consistent with the lack of strong nuclear-receptor-binding activity (E.K. et al., manuscript in preparation). The sequences at residues 111-118 and 913-920, which contain prolines and are unlikely to adopt $\alpha$-helical structure, did not interact with liganded ER (Fig. 1a), indicating that appropriate secondary structure is probably a prerequisite for binding of LXXLL sequences to nuclear receptors.

$\mathrm{CBP} / \mathrm{p} 300$ proteins, originally identified as co-activators for the transcription factor $\mathrm{CREB}^{17,18}$, are co-activators for many other transcription factors, including nuclear receptors ${ }^{4,5,8,9}$, and may integrate several signalling pathways ${ }^{4}$. CBP binds directly to nuclear receptors through its $\mathrm{N}$-terminal 101 amino acids ${ }^{4}$, and has a possible retinoid-receptor (RXR)-specific binding site located between residues 356 and 495 (ref. 8). Our analysis shows that the CBP sequence harbours copies of the LXXLL motif at positions 68 75 and 356-364, which are conserved in the p300 sequence (amino acids 80-90 and 341-351; Fig. 2a). When tested in the two-hybrid assay, the $\mathrm{N}$ terminus of CBP (amino acids 1-101; data not shown) and the LXXLL motif at residues $68-75$ of the CBP sequence (Fig. 1a) show ligand-dependent binding to ER, but not to the transcriptionally defective ER mutant (Fig. 1a).

To show that the binding of co-activator proteins to nuclear receptors depends on LXXLL motifs, we introduced alanine substitutions in SRC-1a at the conserved leucine couplets at residues $636 / 7,693 / 4,752 / 3$ and $1438 / 9$ to generate a mutant protein (SRC1a-M1234) in which all four functional binding motifs were disabled. We then compared the ability of in vitro translated SRC1a and SRC1a-M1234 to bind to the LBD of the mouse ER fused to glutathione $S$-transferase (GST-AF2). Whereas wild-type SRC-1a protein showed ligand-dependent binding to GST-AF2, SRC1a-M1234 did not bind (Fig. 3a). To confirm that the structure of SRC1a-M1234 was not disrupted by the mutations, we compared the interaction of the in vitro translated proteins with amino acids 2,058-2,163 of CBP, defined as the SRC-1 binding domain ${ }^{4}$. Both proteins still bound strongly to GSTCBP (Fig. 3a), indicating that this function was maintained in the mutant SRC-1 protein. In addition, increasing concentrations of a peptide (P1) corresponding to the motif at the $\mathrm{C}$ terminus of SRC-1a competed with SRC-1a for binding to GST-AF2, but a mutant peptide (P2) did not (Fig. 3b).

To show that LXXLL motifs are necessary for the function of SRC-1 in vivo, we compared the abilities of wild-type and mutant SRC-1 to enhance the activity of mouse ER in transient transfection experiments. Unlike SRC-1, which enhanced the activity of the ER, the SRC-1 mutant reduced the transcription of the reporter gene (Fig. 3c). This apparent dominant-negative property of the mutant is probably due to its ability to interact with CBP but not with nuclear receptors (Fig. 3a). Given that SRC-1 and CBP/p300 may exist as a complex in vivo and that CBP can also bind nuclear receptors ${ }^{4,8}$, our results suggest that interaction between nuclear receptors and CBP does not compensate for the inability of the SRC-1a mutant protein to bind nuclear receptors, at least under conditions.

The sequences of other nuclear-receptor-binding proteins contain one or more copies of the LXXLL motif (Fig. 2a). The incidence of this motif in the sequences of RIP-140, SRC-1a, TIF-1, TIF-2, $\mathrm{CBP}$ and $\mathrm{p} 300$, together with the boundaries of the known receptor interaction domains in these proteins, is shown in Fig. 2b. The motif was also identified in several other proteins that may interact with nuclear receptors, including Ara70 (ref. 19), SWI3 (ref. 20) and the RelA (p65) subunit of NF- $\kappa B^{21}$, although the receptor-interaction
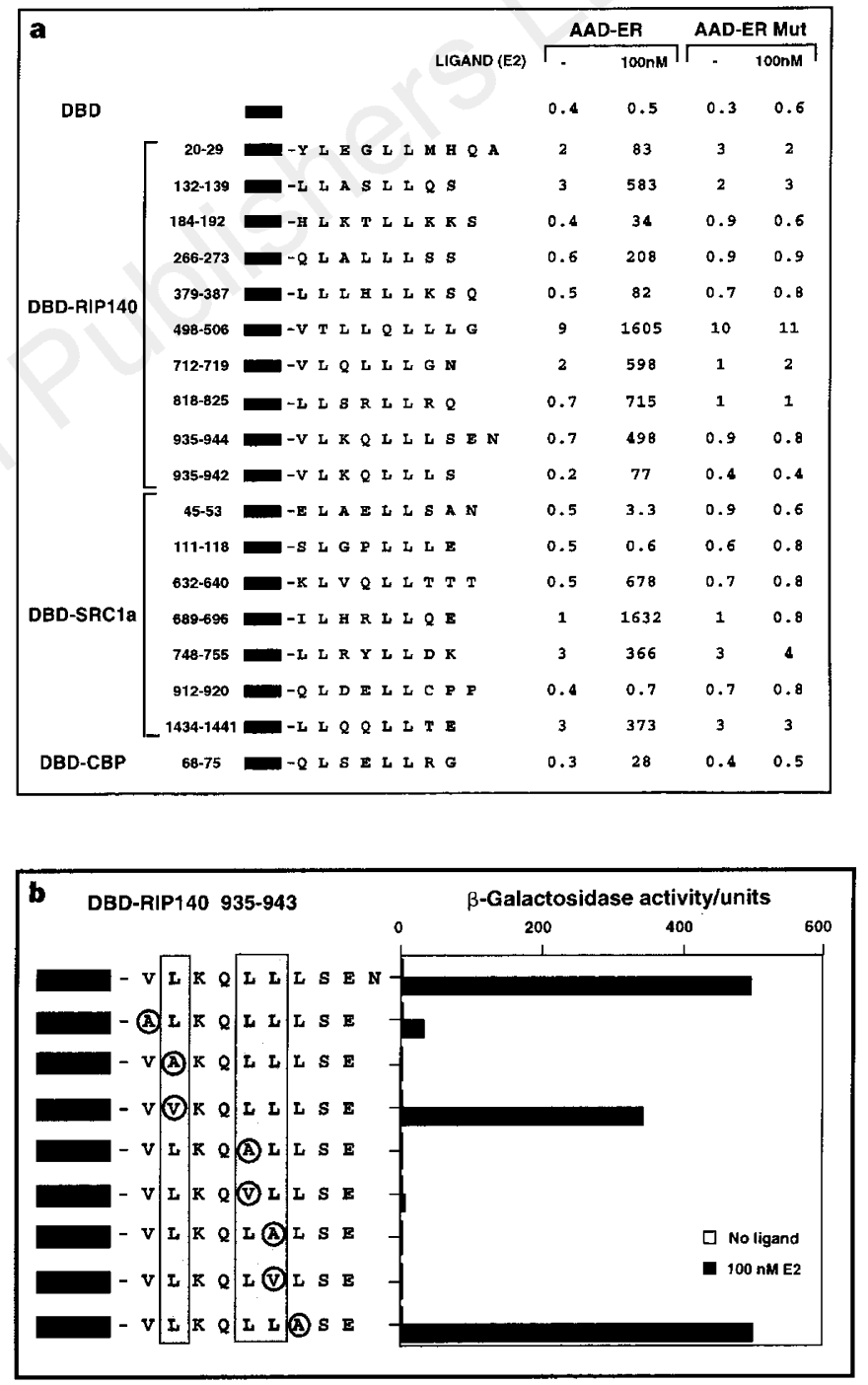

Figure 1 Interaction of $L X X L L$ motifs derived from co-activators with the ER. a, The ability of LXXLL motifs, derived from the proteins RIP-140, SRC-1a and CBP, to interact with the LBDs of wild-type or mutant ER was determined by two-hybrid analysis in yeast. DBD-LXXLL proteins were coexpressed with $A A D-E R$ or AAD-ER Mut, which consist of an acidic activation domain (AAD) fused to the LBD of wild-type ER, or a transcriptionally defective ER mutant, respectively. Reporter activities were determined in the presence or absence of $10^{-7} \mathrm{M} 17-\beta$ oestradiol (E2) and expressed as units of $\beta$-galactosidase activity. $\mathbf{b}$, Effects of mutations in the RIP-140 LXXLL motif located at amino acids 935-943 on binding of AAD-ER. Conserved leucine residues are boxed and mutated residues are circled. The reporter activity was determined in the presence (black bars) or absence (white bars) of $10^{-7} \mathrm{M} \mathrm{E2}$. 


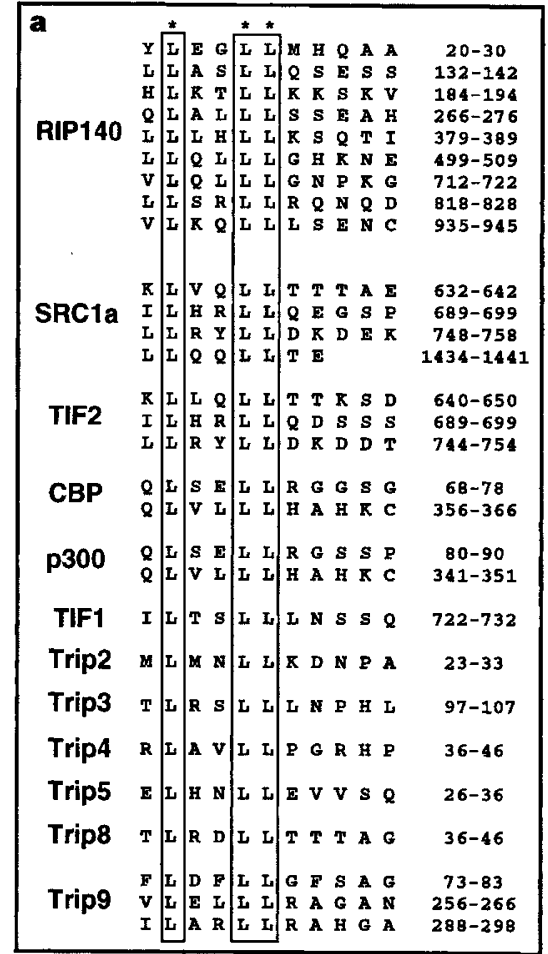

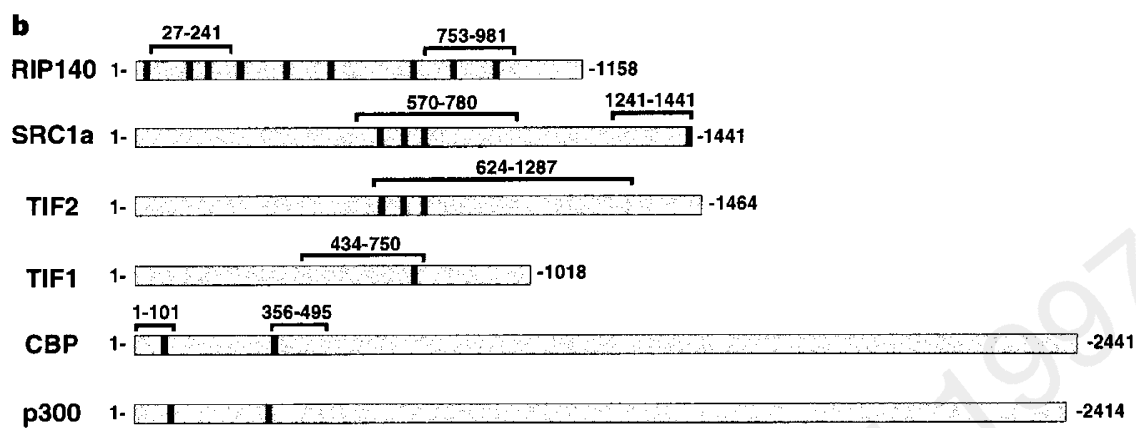

Figure 2 The $L X X L L$ sequence is a signature motif in proteins that bind the LBDs of nuclear receptors. a, Alignment of LXXLL motif sequences present in human RIP-140 (ref. 10), human SRC-1 (our unpublished data), mouse TIF-2 (ref. 6), mouse CBP ${ }^{17,18}$ p300 (ref. 26), mouse TIF-1 (ref. 11) and human TRIP proteins ${ }^{12}$. The conserved leucines are boxed and the amino-acid numbers are given for each motif. $\mathbf{b}$, The incidence of LXXLL motifs (black bars) in sequences of proteins that bind nuclear receptors. The amino-acid boundaries of the nuclear-receptor binding sites are also shown.
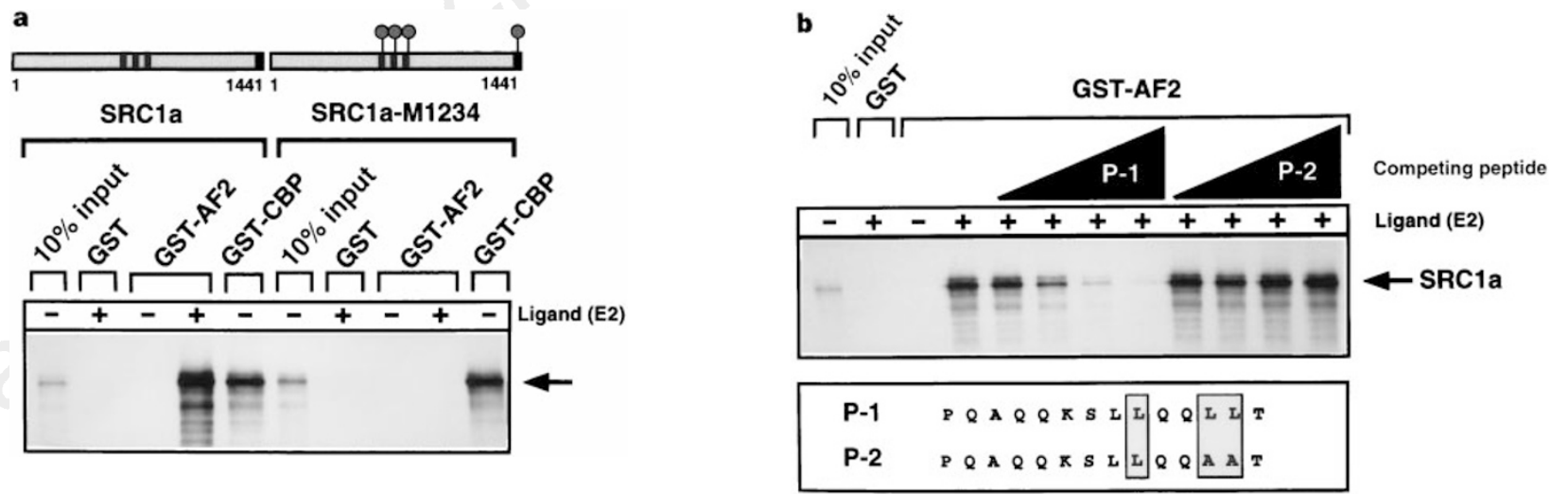

Figure $3 L X X L L$ motifs are required for binding of $S R C-1$ to the ER $L B D$ in vitro and for the ability of SRC-1 to enhance ER activity in vivo. a, Wild-type (SRC-1a) and mutant (SRC1a-M1234) SRC1 proteins. Black bars represent the approximate locations of the LXXLL binding motifs in the linear SRC-1 a sequence; black circles indicate sites of mutation of LXXLL binding motifs in which conserved leucine residues are replaced by alanines. Binding of wild-type SRC-1a or SRC1a-M1234 mutant to GST alone, to the LBD (amino acids 313-599) of ER (GST-AF2), or the SRC-1 binding domain (amino acids 2,058-2,163) of CBP (GST-CBP) in the presence $(+)$ or absence $(-)$ of $10^{-6} \mathrm{M}$ E2. Signals obtained with $10 \%$ of the input of ${ }^{35}$ S-labelled wild-type and mutant SRC-1 proteins are shown. $\mathbf{b}$, The ability of increasing amounts of peptides $\mathrm{P} 1$ and $\mathrm{P} 2$ to compete with wild-type SRC-1a for binding to GST-AF2 in the presence of ligand. Sequences of the P1 and P2 peptides are given underneath; conserved leucines and alanine substitutions are boxed. c, Wild-type but not mutant SRC-1 potentiates activation by ER of the reporter gene 2ERE-pS2-CAT in transiently transfected HeLa cells. Reporter activities obtained from extracts of transfected cells grown in the absence or presence of ligand $\left(10^{-8} \mathrm{M}\right.$ E2). The amounts of ER, SRC1-WT and SRC1-Mut expression plasmids used for transfection are indicated (ng DNA). Activities were averaged from duplicates. 
domains in these proteins have not been mapped. The ability of other proteins containing LXXLL motifs to bind to nuclear receptors will depend on their subcellular localization, as well as on the $\alpha$ helicity and surface-accessibility of the motifs.

We have identified a signature sequence that is present in a group of diverse nuclear proteins, including co-activators, and which is necessary and sufficient for their binding to liganded nuclear receptors. We have shown that the motif is essential for the function of SRC-1 as a coactivator of ER in vivo. As many nuclear-receptorbinding proteins contain multiple copies of the LXXLL motif, it remains unclear whether this facilitates the contact of partners in homo- and heterodimeric nuclear receptors, or whether it provides an alternative interaction surface to accommodate conformational changes imposed by the binding of nuclear receptors to different response elements. Systematic mutation of LXXLL motifs in coactivators such as SRC-1 and CBP should reveal the crosstalk or synergy that exists between different signal transduction pathways and provide a better understanding of their proposed roles as coactivators and integrators.

Note added in proof: A recent study has shown that residues 722 732 of the protein TIF- $1 \alpha$ mediate its binding to nuclear receptors (ref. 27).

\section{Methods}

Two-hybrid interaction assays. The yeast reporter strain used for all twohybrid assays was W303-1B (HML $\alpha$ MAT $\alpha$ HMRa his3-11,15 trp-1 ade2-1 can1-100 leu2-3,11, ura3), carrying the plasmid pRL $\Delta 21-$ U3ERE which contains a lacZ reporter gene driven by three oestrogen-response elements $(E R E s)^{22}$. Plasmids pBL1 and pASV3, which express the human ER DBD and the VP16 acidic activation domain (AAD), respectively ${ }^{23}$, were used to generate DBD or AAD fusion proteins for two-hybrid interaction analysis. DBDLXXLL motif fusion proteins were generated by ligation of phosphorylated annealed oligonucleotide pairs into the pBL1 vector. AD-ER was constructed by cloning a PCR fragment encoding amino acids 282-595 of the human ER into pASV3. AAD-ER Mut was constructed similarly, except that amino acids M543 and L544 or ER were mutated to alanines by recombinant PCR. All fusion constructs were fully sequenced. Transformants containing the plasmids were obtained by selection for the appropriate plasmid markers and were grown to late $\log$ phase in $15 \mathrm{ml}$ selective medium (yeast nitrogen base, containing $1 \%$ glucose and appropriate supplements) in the presence or presence of $10^{-7} \mathrm{M} 17-\beta$-oestradiol (E2). Expression of DBD and AAD fusion proteins in yeast cell-free extracts was verified by immunodetection using a monoclonal antibody recognizing the human ER (gift from P. Chambon). The antibody recognizes the ' $F$ ' region of the LBD in the human $\mathrm{ER}$, and also the ' $\mathrm{F}$ ' region tag at the $\mathrm{N}$ termini of the DBD fusion protein ${ }^{23}$. Equal amounts of protein were electrophoresed on polyacrylamide gels and transferred to nitrocellulose for western blotting. Preparation of cell-free extracts by the glass-bead method and $\beta$-galactosidase assay of the extracts were done as described ${ }^{22}$. Two-hybrid experiments were repeated several times, and results shown in Fig. 1a,b are reporter activities measured in a single representative experiment. $\beta$-Galactosidase activity is expressed as nmol $\min ^{-1}$ per $\mu \mathrm{g}$ protein.

Assay of in vitro binding and peptide inhibition. GST-AF2 consists of the LBD of the mouse ER (amino acids 313-599) fused to GST ${ }^{24}$. GST-CBP consists of GST fused to the SRC1-binding domain of CBP and was constructed by cloning a PCR fragment encoding residues 2,058-2,163 of mouse CBP into the vector pGEX2TK (Pharmacia). Human SRC-1a and SRC-le cDNAs were isolated from a human B-cell cDNA library and cloned into a modified version of the expression vector pSG5. SRC-1a M1234 were constructed by recombinant PCR to introduce the leucine-to-alanine mutations at positions 636/ $637,693 / 694,752 / 753$, and $1,438 / 1,439$ or $636 / 637,693 / 694$ and $752 / 753$, respectively. ${ }^{35}$ S-labelled SRC-1 proteins were generated by in vitro translation and tested for interaction with GST proteins in the presence or absence of $10^{-6} \mathrm{M}$ oestradiol (E2) as described ${ }^{15}$. Peptide P1 or P2 at $4 \mathrm{mg} \mathrm{ml}^{-1}$ was added to GST-binding reactions immediately before the ligand. The increasing concentrations of peptide added in competition experiments were 2.5, 5, 12.5 and $25 \mu \mathrm{M}$.

Transient reporter assays. HeLa cells were transfected with $1 \mu \mathrm{g}$ reporter 2ERE-pS2-CAT ${ }^{25}, 150 \mathrm{ng} \beta$-galactosidase expression plasmid (internal control), $10 \mathrm{ng}$ ER expression plasmid, and 50 or $200 \mathrm{ng}$ SRC1 expression plasmids or empty vector per well (in duplicate) using 24-well plates. Transfected cells were incubated overnight in DMEM medium without phenol red and containing $10 \%$ charcoal-treated FBS, and washed in fresh medium before addition of ligand $\left(10^{-8} \mathrm{M}\right.$ E2) or vehicle. After $40 \mathrm{~h}$, cells were collected and extracts analysed for chloramphenicol acetyltransferase (CAT) and $\beta$-galactosidase activities $^{14,15}$. $\beta$-Galactosidase activity was used to correct for differences in transfection efficiency.

Received 10 December 1996; accepted 8 May 1997.

1. Beato, M., Herrlich, P. \& Shutz, G. Steroid-hormone receptors—-many actors in search of a plot. Cell 83, 851-857 (1995).

2. Mangelsdorf, D. J. et al. The nuclear receptor superfamily: the second decade. Cell 83, 835-839 (1995).

3. Onate, S. A., Tsai, S. Y., Tsai, M.-J. \& O’Malley, B. W. Sequence and characterization of a coactivator for the steroid hormone receptor superfamily. Science 270, 1354-1357 (1995).

4. Kamei, Y. et al. A CBP integrator complex mediates transcriptional activation and AP-1 inhibition by nuclear receptors. Cell 85, 403-414 (1996).

5. Yao, T.-P., Ku, G., Zhou, N., Scully, R. \& Livingston, D. M. The nuclear hormone receptor coactivator SRC-1 is a specific target of p300. Proc. Natl Acad. Sci. USA 93, 10626-10631 (1996).

6. Voegel, J. J., Heine, M. J. S., Zechel, C., Chambon, P. \& Gronemeyer, H. TIF2, a 160 kDa transcriptional mediator for the ligand-dependent activation function AF-2 of nuclear receptors. EMBO J. 15, 101108 (1996).

7. Hong, H., Kohli, K., Trivedi, A., Johnson, D. L. \& Stallcup, M. R. Grip1, a novel mouse protein that serves as a transcriptional coactivator in yeast for the hormone-binding domains of steroid-receptors. Proc. Natl Acad. Sci. USA 93, 4948-4952 (1996).

8. Chakravarti, D. et al. Role of CBP/p300 in nuclear receptor signalling. Nature 383, 99-103 (1996)

9. Hanstein, B. et al. p300 is a component of an estrogen receptor coactivator complex. Proc. Natl Acad. Sci. USA 93, 11540-11545 (1996).

10. Cavaillès, V. et al. Nuclear factor RIP140 modulates transcriptional activation by the estrogen receptor. EMBO J. 14, 3741-3751 (1995).

11. Le Douarin, B. et al. The N-terminal part of TIF1, a putative mediator of the ligand-dependent activation function (AF-2) of nuclear receptor, is fused to $\mathrm{B}-\mathrm{raf}$ in the oncogenic protein T18. EMBO J. 14, 2020-2033 (1995).

12. Lee, J. W., Ryan, F., Swaffield, J. C., Johnston, S. A. \& Moore, D. D. Interaction of thyroid-hormone receptor with a conserved transcription mediator. Nature 374, 91-94 (1995).

13. vom Baur, E. et al. Differential ligand-dependent interactions between the AF-2 activating domain of nuclear receptors and the putative transcriptional intermediary factors mSUG1 and TIF1. EMBO J. 15, 110-124 (1996).

14. Danielian, P. S., White, R., Lees, L. A. \& Parker, M. G. Identification of a conserved region required for hormone dependent transcriptional activation by steroid hormone receptors. EMBO J. 11, 1025-1033 (1992)

15. L’Horset, F., Dauvois, S., Heery, D. M., Cavaillès, V. \& Parker, M. G. RIP-140 interacts with multiple nuclear receptors by means of two distinct sites. Mol. Cell. Biol. 16, 6029-6036 (1996).

16. Rost, B. \& Sander, C. Improved prediction of protein secondary structure by use of sequence profiles and neural network. Proc. Natl Acad. USA 90, 7558-7562 (1993).

17. Kwok, R. P. S. et al. Nuclear protein CBP is a coactivator for the transcription factor CREB. Nature 370, 223-226 (1994)

18. Arias, J. et al. Activation of cAMP and mitogen responsive genes relies on a common nuclear factor. Nature 370, 226-229 (1994).

19. Yeh, S. \& Chang, C. Cloning and characterization of a specific coactivator, $\mathrm{ARA}_{70}$, for the androgen receptor in human prostate cells. Proc. Natl Acad. Sci. USA 93, 5517-5521 (1996).

20. Yoshinaga, S. K., Peterson, C. L., Herskowitz, I. \& Yamamoto, K. R. Roles of SWI1, SWI2, and SWI3 proteins for transcriptional enhancement by steroid receptors. Science 258, 1598-1604 (1992).

1. Stein, B. \& Yang, M. X. Repression of the interleukin-6 promoter by estrogen receptor is mediated by NF-K and C/EBPß. Mol. Cell. Biol. 15, 4971-4979 (1995).

22. Metzger, D., Losson, R., Bornert, J.-M., Lemoine, Y. \& Chambon, P. Promoter specificity of the two transcriptional activation functions of the human oestrogen receptor in yeast. Nucleic Acids Res. 20, 2813-2817 (1992).

23. Le Douarin, B., Pierrat, B., vom Baur, E., Chambon, P. \& Losson, R. A new version of the two-hybrid assay for detection of protein-protein interactions. Nucleic Acids Res. 23, 876-878 (1995).

24. Cavaillès, V., Dauvois, S., Danielian, P. S. \& Parker, M. G. Interaction of proteins with transcriptionally active estrogen receptors. Proc. Natl Acad. Sci. USA 91, 10009-10013 (1994).

25. Montano, M. M., Ekena, K., Krueger, K. D., Keller, A. L. \& Katsenellenbogen, B. S. Human estrogenreceptor ligand activity inversion mutants-receptors that interpret antiestrogens as estrogens and estrogens as antiestrogens and discriminate among different antiestrogens. Mol. Endocrinol. 10, 230242 (1996)

26. Eckner, R. et al. Molecular cloning and functional analysis of the adenovirus E1A associated $300 \mathrm{kD}$ protein (p300) reveals a protein with properties of a transcriptional adaptor. Genes Dev. 8, 869-884 (1994).

27. Le Douavin, B. et al. A possible involvement of TIF $1 \alpha$ and TIF1 $\beta$ in the epigenetic control of transcription by nuclear receptors. EMBO J. 15, 6701-6715 (1996)

Acknowledgements. We thank our colleagues for discussion and for communicating unpublished results; P. Freemont, N. Jones and A. Parker for their suggestions and for critically reading the manuscript; P. CAT; N. Jon for the yea photography; and G. Clark for automated sequencing. D.M.H. and E.K. were supported by grants from the European Community TMR program and the Netherlands Organisation of Scientific Research (NWO), respectively.

Correspondence and requests for materials should be addressed to M.G.P. (e-mail: m.parker@icrf. icnet.uk). 